
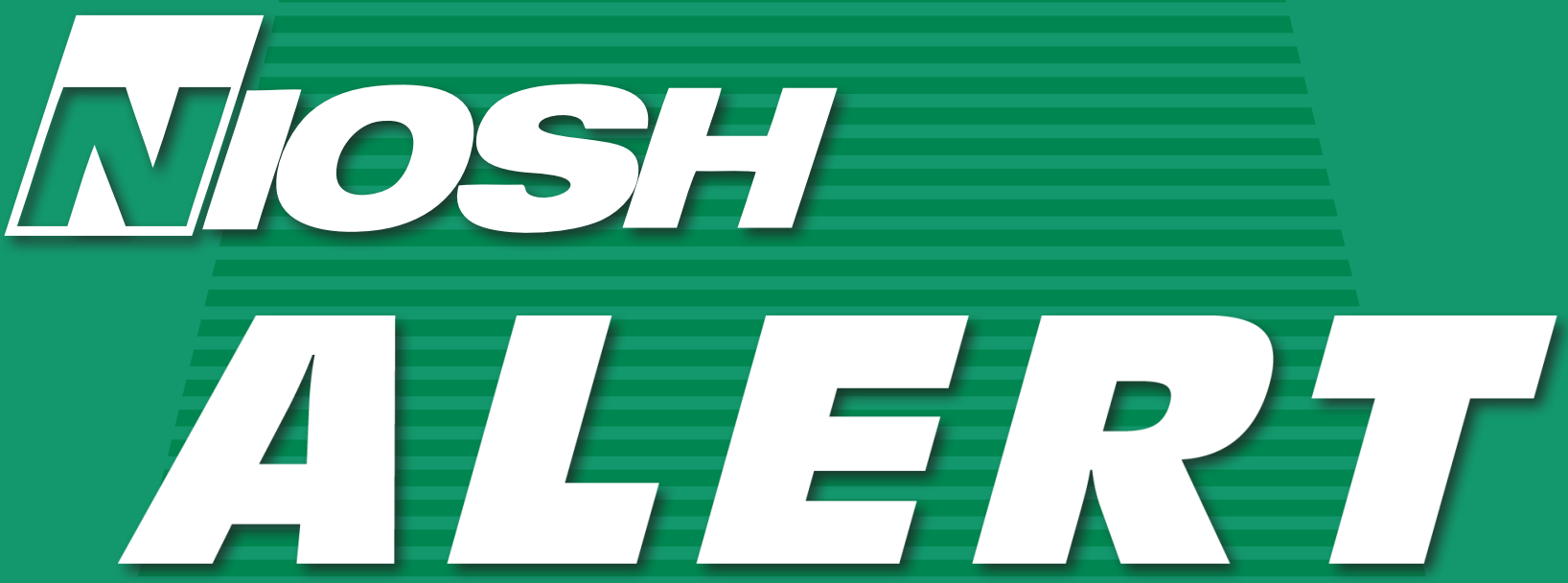

\title{
Preventing Sensitization and Disease from Beryllium Exposure
}

DEPARTMENT OF HEALTH AND HUMAN SERVICES

Centers for Disease Control and Prevention

National Institute for Occupational Safety and Health

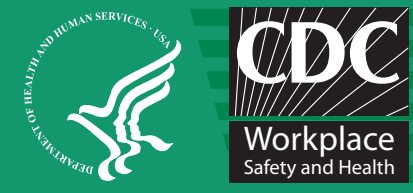

Nosh 


\section{This document is in the public domain and may be freely copied or}

\section{reprinted.}

\section{DISCLAIMER}

Mention of any company or product does not constitute endorsement by the National Institute for Occupational Safety and Health (NIOSH). In addition, citations to Web sites external to NIOSH do not constitute NIOSH endorsement of the sponsoring organizations or their programs or products. Furthermore, NIOSH is not responsible for the content of these Web sites.

\section{ORDERING INFORMATION}

To receive documents or more information about occupational safety and health topics, contact $\mathrm{NIOSH}$ at

$$
\begin{gathered}
\text { 1-800-CDC-INFO (1-800-232-4636) } \\
\text { TTY: } 1-888-232-6348 \\
\text { E-mail: cdcinfo@cdc.gov }
\end{gathered}
$$

or visit the NIOSH Web site at www.cdc.gov/niosh

For a monthly update on news at NIOSH, subscribe to NIOSH eNews by visiting www.cdc. gov/niosh/eNews.

DHHS (NIOSH) Publication Number 2011-107

February 2011 


\section{Niosh ALERT}

\section{Preventing Sensitization and Disease from Beryllium Exposure}

\section{WARNING!}

Workers exposed to particles, fumes, mists, or solutions from beryllium-containing materials may develop beryllium sensitization or chronic beryllium disease, a potentially disabling or even fatal respiratory disease.

\section{What Workers Should Do}

$\mathrm{NIOSH}$ recommends that workers exposed to particles, fumes, mists, or solutions from beryllium-containing materials take the following steps to protect themselves:

- Understand the risks and follow all proper procedures for working with beryllium-including participation in safety training.

- Keep beryllium out of the lungs:

- Make sure that beryllium dusts, fumes, mists, and beryllium-containing solutions and suspensions are controlled at their sources.

- Participate in respiratory protection programs when advised to do so.

- Keep beryllium-containing dusts and solutions off the skin:

- Keep work surfaces and work areas clean.
- Participate in skin protection programs. These programs may include wearing gloves and company-issued clothing (with long sleeves and long pants) and showering at the end of the workday.

- Do not store or consume food, drinks, tobacco products, or cosmetics in beryllium work areas.

- Do not use cleaning methods that may cause dust to become resuspended in air (dry sweeping, compressed air, and other dust-generating methods, for example). Better methods include HEPA-filtered vacuums or wet cleaning methods that do not produce splash or spray.

- Prevent beryllium dusts and other contaminants from leaving beryllium work areas on your skin, clothing, shoes, and tools.

- Participate in workplace medical surveillance so that risks related to job tasks can be identified and prevented. 
- Seek medical attention for any chronic cough or shortness of breath, which may indicate chronic beryllium disease.

- Seek medical attention for any rash or nonhealing cut or wound.

\section{What Employers Should Do}

$\mathrm{NIOSH}$ recommends that employers of workers exposed to particles, fumes, mists, or solutions from beryllium-containing materials take the following steps to protect workers, contractors, and visitors:

- Know the beryllium content of all materials in the workplace. The manufacturers or suppliers of materials containing greater than $0.1 \%$ beryllium are required to provide this information on Material Safety Data Sheets.

- Substitute less hazardous materials for those containing beryllium whenever feasible.

- Minimize the number of workers exposed to beryllium dusts, fumes, mists, and berylliumcontaining solutions and suspensions.

- Install, use, and maintain effective engineering controls for processes that create beryllium dusts, fumes, mists, and beryllium-containing solutions and suspensions.

- Keep airborne concentrations of beryllium as low as possible, since a safe exposure limit for beryllium has not been determined.

- Monitor airborne beryllium concentrations to document the effectiveness of efforts to reduce airborne exposures.
- Inform workers about the risks of beryllium sensitization, chronic beryllium disease, and lung cancer, and the proper procedures for working with beryllium-containing materials.

- Keep beryllium dusts, fumes, mists, and beryllium-containing solutions and suspensions confined to the immediate work area.

- Do not use cleaning methods that may cause dust to become resuspended in air (dry sweeping, compressed air, and other dust-generating methods, for example). Better methods include HEPA-filtered vacuums or wet cleaning methods that do not produce splash or spray.

- Prevent beryllium dusts and other contaminants from leaving beryllium work areas on workers' skin, clothing, shoes, and tools.

- Identify and clean areas outside the beryllium work zone that may have become contaminated before these recommendations were implemented.

- Establish and maintain an appropriate respiratory protection program as needed.

- Establish and maintain a skin protection program to protect workers' skin from contamination with beryllium dusts and solutions:

- Keep work surfaces and work areas clean.

- Provide work gloves, long-sleeved shirts, long pants, and shoes that remain at the workplace.

- Provide showering and changing facilities.

- Conduct medical surveillance for sensitization using the beryllium lymphocyte proliferation 
test for workers who come in contact with beryllium dusts, fumes, mists, and berylliumcontaining solutions and suspensions:

- Identify higher-risk jobs and processes to prioritize prevention efforts and evaluate their effectiveness in decreasing the risk of sensitization.

- Ensure that sensitized workers identified through surveillance are referred for medical testing (1) to determine whether they have chronic beryllium disease, (2) to establish radiographic and lung function baselines for follow-up testing, and (3) receive counseling.
For additional information, see NIOSH Alert: Preventing Sensitization and Disease from Beryllium Exposure [DHHS (NIOSH) Publication No. 2011-107]. Single copies of the Alert are available free from the following:

Telephone: 1-800-CDC-INFO (1-800-232-4636)

TTY: 1-888-232-6348 - E-mail: cdcinfo@cdc.gov

or visit the NIOSH Web site at www.cdc.gov/niosh

For a monthly update on news at $\mathrm{NIOSH}$, subscribe to NIOSH eNews by visiting www.cdc.gov/niosh/eNews.

\section{DEPARTMENT OF HEALTH AND HUMAN SERVICES}

Centers for Disease Control and Prevention National Institute for Occupational Safety and Health

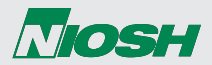





\section{ALERTA DE NTOSH}

\section{Prevención de la sensibilización y la enfermedad por exposición al berilio}

\section{¡ADVERTENCIA!}

Los trabajadores expuestos a partículas, emisiones, vapores o soluciones de materiales que contienen berilio pueden presentar sensibilización al berilio o enfermedad crónica por berilio, que es una afección respiratoria potencialmente discapacitante o incluso mortal.

\section{Lo que los trabajadores deben hacer}

$\mathrm{NIOSH}$ recomienda que los trabajadores expuestos a las partículas, emisiones, vapores o soluciones de materiales que contienen berilio realicen los siguientes pasos para protegerse:

- Conozca los riesgos y siga todos los procedimientos adecuados para trabajar con berilio (como participar en cursos sobre seguridad).

- Evite que el berilio se introduzca en sus pulmones:

- Asegúrese de que haya un control en las fuentes de polvo, emisiones, vapores, soluciones y suspensiones que contienen berilio.

- Participe en programas de protección respiratoria cuando se lo indiquen.

- Evite el contacto de la piel con el polvo y las soluciones que contienen berilio:
- Mantenga limpias las superficies y las áreas de trabajo.

- Participe en los programas de protección de la piel. Estos programas pueden incluir el uso de guantes y ropa proporcionados por la empresa (de mangas largas y con pantalones largos) y tener que ducharse al final de la jornada laboral.

- No guarde ni consuma alimentos, bebidas, productos de tabaco o cosméticos en áreas donde se trabaja con berilio.

- No utilice métodos de limpieza que puedan causar que el polvo vuelva a suspenderse en el aire (por ejemplo, barrido en seco, aire comprimido y otros métodos que producen polvo). Los mejores métodos incluyen las aspiradoras con filtro HEPA o métodos de limpieza húmedos que no salpican ni rocían.

- Evite que el polvo de berilio y otros contaminantes salgan de las áreas donde se 
trabaja con berilio a través de su piel, ropa, zapatos y herramientas.

- Participe en la vigilancia médica del lugar de trabajo para que los riesgos relacionados con las tareas del trabajo se puedan identificar y prevenir.

- Busque atención médica para cualquier tos crónica o dificultad para respirar, que puede indicar la presencia de la enfermedad crónica por berilio.

- Busque atención médica para cualquier irritación en la piel o heridas o cortes que no se curan.

\section{Lo que los empleadores deben hacer}

NIOSH recomienda que los empleadores de trabajadores expuestos a partículas, emisiones, vapores o soluciones de materiales que contienen berilio realicen los siguientes pasos para proteger a los empleados, contratistas y visitantes:

- Conozca el contenido de berilio de todos los materiales del lugar de trabajo. Los fabricantes o proveedores de materiales que contienen berilio en mayores cantidades que 0.1\% están obligados a proporcionar esta información en las hojas informativas de seguridad de los materiales (Material Safety Data Sheets).

- Siempre que sea posible, sustituya los materiales que contengan berilio por otros menos peligrosos.

- Reduzca el número de trabajadores expuestos al polvo, las emisiones y los vapores de berilio y a las soluciones y suspensiones que contienen berilio.
Instale, use y mantenga controles de ingeniería eficaces para los procesos que crean polvo, emisiones y vapores de berilio y soluciones y suspensiones que contienen berilio.

- Mantenga las concentraciones aéreas de berilio lo más bajas posible, ya que aún no se ha determinado un límite de exposición al berilio que sea seguro.

- Vigile las concentraciones aéreas de berilio con el fin de poder documentar la eficacia de los esfuerzos para reducir las exposiciones aerotransportadas.

- Informe a los trabajadores sobre los riesgos de sensibilización al berilio, enfermedad crónica por berilio y cáncer de pulmón, y los proce-dimientos adecuados para trabajar con materiales que contienen berilio.

- Mantenga el polvo, las emisiones y los vapores de berilio y las soluciones y suspensiones que contienen berilio dentro del espacio de la zona de trabajo inmediata.

- No utilice métodos de limpieza que puedan causar que el polvo vuelva a suspenderse en el aire (por ejemplo, barrido en seco, aire comprimido y otros métodos que producen polvo). Los mejores métodos incluyen las aspiradoras con filtro HEPA o métodos de limpieza húmedos que no salpican ni rocían.

- Evite que el polvo de berilio y otros contaminantes se transporten fuera de las áreas donde se trabaja con berilio a través de la piel, la ropa, los zapatos y las herramientas de los trabajadores. 
Identifique y limpie las áreas fuera de la zona de trabajo con el berilio que puedan haberse contaminado antes de que estas recomendaciones fuesen implementadas.

- Establezca y mantenga un programa de protección respiratoria adecuado cuando sea ne-cesario.

- Establezca y mantenga un programa de protección de la piel para proteger a los trabajadores de la contaminación con polvo y soluciones con berilio:

- Mantenga limpias las superficies y las áreas de trabajo.

- Proporcione guantes de trabajo, camisas de manga larga, pantalones largos y zapatos que permanezcan en el lugar de trabajo.

- Proporcione espacio para ducharse y vestuarios.

- Lleve a cabo un programa de vigilancia médica para detectar la sensibilización al berilio con la prueba de proliferación de linfocitos por berilio para los trabajadores que están en contacto el polvo, las emisiones, los vapores, las soluciones y suspensiones que contienen berilio:

- Identifique los puestos de trabajo y los procesos de alto riesgo para dar prioridad a los esfuerzos de prevención y evaluar su eficacia en la disminución del riesgo de sensibilización.

- Asegúrese de que se remita a los trabajadores sensibilizados identificados a través del programa de vigilancia para realizarse análisis médicos (1) para determinar si tienen la enfermedad crónica por berilio, (2) para establecer una referencia radiológica y del funcionamiento respiratorio para las pruebas de seguimiento y (3) recibir asesoramiento.

Para obtener más información, consulte la Alerta de NIOSH: Prevención de la sensibilización y de la enfermedad por exposición al berilio [DHHS (NIOSH) Publicación núm. 2011-107]. Solicite copias gratuitas de esta Alerta escribiendo a:

Teléfono: 1-800-CDC-INFO (1-800-232-4636)

TTY: 1-888-232-6348

Correo electrónico: cdcinfo@cdc.gov

o visite el sitio web de NIOSH: www.cdc.gov/niosh

Para recibir boletines mensuales de actualización de $\mathrm{NIOSH}$, visite www.cdc.gov/niosh/eNews y suscríbase al boletín NIOSH eNews (en inglés).

Departamento de Salud y Servicios Humanos Centros para el Control y la Prevención de Enfermedades Instituto Nacional para la Seguridad y Salud Ocupacional 



\section{Nosh \\ ALERT}

\section{Preventing Sensitization and Disease from Beryllium Exposure}

The National Institute for Occupational Safety and Health (NIOSH) requests assistance in preventing beryllium sensitization and chronic beryllium disease. Development of these conditions requires exposure to beryllium and is affected by both job tasks and genetic factors. Some jobs or tasks involve exposures that increase the risk of sensitization and disease. Some people have inherited genes that make them more likely to become sensitized or develop chronic beryllium disease when exposed.

$\mathrm{NIOSH}$ requests that the information in this Alert be brought to the attention of workers and employers by the following: trade associations, editors of trade journals, safety and health officials, labor organizations, members of the academic and public health communities, advocacy groups, workers' compensation insurance companies, manufacturers and distributors of materials that contain beryllium, and the mass media.

\section{BACKGROUND}

Risks may be associated with all berylliumcontaining materials (including alloys of beryllium as well as beryllium metal and oxide materials) when these materials are heated or worked to create particles, fumes, or mists.

Beryllium may be encountered as any of the following:

- Compounds extracted from beryl and bertrandite minerals

- A refined metal with unique physical properties including high strength, lightness (low density), stiffness, dimensional stability, fidelity of vibration transmission, high thermal and electrical conductivity, neutron-moderating properties, and X-ray transparency

- A ceramic with electrical resistivity, a high melting point, and excellent thermal conductivity 
An alloy or mixture of metals having special properties including antigalling behavior, castability, corrosion resistance, electrical conductivity, durability, flexibility, nonsparking behavior, springiness (elasticity), and wear resistance*

- A byproduct of recycling materials that contain beryllium, such as alloys

See the Appendix for examples of industries that use beryllium and products that may contain beryllium.

Material Safety Data Sheets (MSDSs) provide information about the beryllium content of products that contain more than $0.1 \%$ beryllium. At lower concentrations, employers and workers may not be aware of the presence of beryllium; but health risks may exist if the beryllium-containing material is dispersed as a dust, fume, or berylliumcontaining solution that can be inhaled or come into contact with unprotected skin.

Cases of beryllium sensitization and chronic beryllium disease have been reported in which exposures were below the current Occupational Safety and Health Administration (OSHA) Permissible Exposure Limit (PEL) of 2.0 micrograms per cubic meter $\left(\mu \mathrm{g} / \mathrm{m}^{3}\right)$ of air and the current NIOSH Recommended Exposure Limit (REL) of $0.5 \mu \mathrm{g} / \mathrm{m}^{3}$.

\section{BERYLLIUM SENSITIZATION}

A worker's immune system determines whether he or she will develop health problems from working with beryllium. Some workers become sensitized to beryllium, which means that exposure to beryllium has triggered the immune system to recognize and

*Copper-beryllium alloys are the most widely used form of beryllium. respond to this metal as a foreign substance. The risk of sensitization is determined by beryllium exposure, but it may be increased by certain genes that have been inherited from either parent.

A blood test-the beryllium lymphocyte proliferation test (BeLPT)-can detect sensitization by measuring how blood cells react to beryllium. It has been used effectively in medical surveillance programs in both private industry and government organizations to identify sensitization among participating workers. However, as with all medical tests, the BeLPT is not perfect: false positive results (a nonsensitized person's test result indicates sensitization) and false negative results (a sensitized person's test result indicates no sensitization) may occur. Results may also vary between clinical laboratories performing the BeLPT. Despite its limitations, the BeLPT is the best available tool to identify sensitization until a more reliable test is developed.

No health symptoms are associated with beryllium sensitization. However, it is believed that a person must first be sensitized before beryllium in the lungs can cause the lung damage (called granulomas) of chronic beryllium disease [1].

Some individuals identified as sensitized with the BeLPT will already have chronic beryllium disease [2]. Those who are sensitized without chronic beryllium disease are at increased risk of developing it in the future. In one study following 55 sensitized individuals without chronic beryllium disease, about $1 / 3$ were diagnosed with the disease within a $4 \frac{1}{2}$ year period of follow-up [3]. However, the overall proportion of all sensitized individuals who will eventually develop chronic beryllium disease is not known. 


\section{DISEASES}

\section{Chronic Beryllium Disease}

Chronic beryllium disease occurs when a sensitized worker's lungs react with beryllium that has been inhaled, producing lung granulomas and scarring.

To determine whether chronic beryllium disease is present, workers with abnormal BeLPT results must have further medical testing. A lung biopsy may be performed to remove small samples of lung tissue. In chronic beryllium disease, granulomas can be seen with a microscope in the biopsy samples. The biopsy test can detect disease before a worker has any symptoms. A lung lavage, where cells are "washed" from the lung, may also be performed and the lavage cells tested for sensitization. Other tests such as chest X-rays, computed axial tomography (CAT) scans of the chest, and pulmonary function tests can also help make the diagnosis of advanced disease.

Chronic beryllium disease has been observed among workers with a variety of exposure histories - long and short duration, high and low air concentrations of beryllium, and any form of beryllium. In many cases, chronic beryllium disease develops while workers are still being exposed to beryllium, occasionally within months of first exposure. In other instances, the disease may not be diagnosed until years after a person has stopped working in the beryllium industry.

Chronic beryllium disease usually has a slow onset of symptoms. It can be so mild at the time of diagnosis that the affected worker has no suspicion that he or she has a lung disease. However, when chronic beryllium disease progresses, the widespread granulomas and associated lung damage cause chronic chest symptoms such as coughing and shortness of breath on exertion. Other symptoms that may develop in some persons with chronic beryllium disease are unusual fatigue, night sweats, and weight loss.

The symptoms and lung function abnormalities often respond to corticosteroid medication such as prednisone or other medications that suppress the immune system response to beryllium. However, these medications do not cure the disease; they have side effects and must usually be taken indefinitely to prevent progressive lung damage or slow the rate of clinical deterioration. Some people with chronic beryllium disease eventually require supplemental oxygen, become severely disabled, and even die because of respiratory failure or insufficiency.

Certain genes appear to cause some beryllium-exposed workers to be more susceptible to beryllium sensitization and chronic beryllium disease [2]. Continuing genetic research may contribute to a better understanding of why some are more susceptible. This research may also lead to prevention of sensitization and disease and the exploration of new treatments for sensitization and disease in affected workers. However, with our current knowledge, genetic testing is not useful in predicting who will develop chronic beryllium disease because (1) the genes linked to sensitization and disease are found in a large percentage of the general population, and (2) sensitization and chronic beryllium disease have developed in some people who do not have these genes. The future usefulness of genetic testing remains to be determined, but it may someday have a role in helping workers make informed decisions about working with beryllium. 


\section{Acute Beryllium Disease}

Acute beryllium disease has been diagnosed in the past, but it is rare today. The disease typically has a quick onset with symptoms resembling those of pneumonia or bronchitis. It occurs after exposure to soluble beryllium salts, which are used in the making of beryllium metal. Acute beryllium disease usually resolves within months of stopping beryllium work, but some affected workers later develop chronic beryllium disease.

\section{Cancer}

Significantly elevated risks of lung cancer have been reported for workers exposed to beryllium; the National Toxicology Program lists it as a known carcinogen [4] and the International Agency for Research on Cancer reaffirmed its classification as carcinogenic to humans [5]. Controlling beryllium exposures to prevent chronic beryllium disease should also reduce the risk for lung cancer.

\section{MEDICAL SURVEILLANCE}

Medical surveillance of a workforce looks at medical test results over time in relation to information about jobs and processes. Medical surveillance of workers exposed to beryllium includes using the BeLPT to identify sentinel (new) cases of sensitization. Identification of sentinel cases may indicate that co-workers are at risk. Surveillance information is used to determine whether some jobs or processes are higher risk than others, to set priorities for making changes to protect workers, and to evaluate the success of efforts to prevent disease. Testing for beryllium sensitization is not a substitute for prevention of beryllium exposure and may not prevent chronic beryllium disease in sensitized individuals.

\section{WORKFORCE SURVEYS}

Since the late 1980s, beryllium-exposed workforces have been surveyed for sensitization to beryllium and chronic beryllium disease. Workers typically complete a questionnaire about their health and work history and submit blood samples that are tested for sensitization to beryllium. Sensitized workers are then further evaluated for chronic beryllium disease. Scientists look for jobs and work tasks in which sensitization and chronic beryllium disease are most common. They may also estimate workers' beryllium exposure to determine whether risk increases as estimated exposure increases.

Researchers have studied various beryllium workplaces, including those in the primary beryllium industry, nuclear weapons facilities, the ceramics industry, mining and ore milling facilities, precision machining plants, beryllium-contaminated buildings undergoing decontamination and decommissioning, workplaces with construction trades workers, and aluminum smelters [1,6-19]. Workers in these studies were exposed to different forms of beryllium, such as beryllium oxide ceramic, pure beryllium metal, and beryllium alloys (primarily copper alloys); they may have been current or former workers.

Workers who refine, prepare, and process beryllium and beryllium-containing materials are at the greatest risk for sensitization and chronic beryllium disease. Sensitization has been found in $1 \%$ to $15 \%$ of workers studied cross-sectionally, with chronic beryllium disease diagnosed in $10 \%$ to $100 \%$ of sensitized workers [2]. In one longitudinal study of a beryllium oxide ceramics worker cohort, the 11-year prevalences of sensitization and chronic beryllium disease were $20 \%$ and $14 \%$, respectively [15]. The risk for 
workers in other industries depends on their potential exposure to dust particles, fumes, mists, and beryllium-containing solutions and suspensions.

\section{Exposure-Related Risks}

Some production jobs have higher rates of sensitization or chronic beryllium disease. Specific jobs or work processes that have been shown to carry a higher risk include machining of ceramics or beryllium metal, ceramics production, work with copper-beryllium rod and wire materials, and engineering, laboratory, and technical jobs [1, 7-10, 14, 17].

Risk is not limited to production workers. In many studies, additional cases of sensitization or chronic beryllium disease were identified among nonproduction workers or workers whose exposure appeared to be minimal, such as secretaries, other clerical workers, and security guards [1, 8-10, 17].

When estimates of beryllium exposure (based on mass concentration of airborne beryllium) were calculated for study participants, no consistent relationship was found between airborne exposure and risk of either sensitization or chronic beryllium disease. In other words, workers with the highest estimated beryllium exposures were not necessarily at the highest risk, and higher risk jobs or processes did not always have the highest beryllium exposure. Other exposure factors may also be important, including chemical form and particle size [20, Chapter 2]. However, control of airborne beryllium exposure is an important part of any workplace program to reduce the risk of sensitization and chronic beryllium disease.

\section{Skin Exposure}

Research suggests that sensitization may result from skin contact with beryllium dusts, fumes, and beryllium-containing solutions and suspensions. In the 1950s, patch testing led to skin sensitization [21]. More recently, researchers observed that tight control of airborne beryllium exposure alone did not prevent sensitization of new workers in the first year or two of their employment [7]. Laboratory researchers demonstrated that (1) mice could become sensitized to beryllium if beryllium was placed on their skin, and (2) tiny particles (dextran beads less than 1 micrometer $(\mu \mathrm{m})$ in diameter) could penetrate intact human skin tissue samples when the skin was flexed, thereby allowing them to reach the layers of the skin where the immune system cells are located and where the sensitization process can begin [22]. Particles larger than $1 \mu \mathrm{m}$ could penetrate only cuts or abrasions. Although research is continuing, NIOSH recommends that employers and workers prevent skin contact with beryllium particles or solutions containing beryllium, including protecting skin cuts and abrasions.

\section{Prevention}

One study at a beryllium oxide ceramics plant has shown that a comprehensive preventive program can reduce the development of sensitization in new workers not previously exposed to beryllium [23]. The program placed special emphasis on preventing the migration of dust and fluids away from work processes and on protection of skin, in addition to engineering controls and respiratory protection [24]. The facility used medical surveillance with the BeLPT to monitor the effectiveness of the program in preventing sensitization. Nine percent of workers hired between 1993 and 1998, before the program started, became sensitized. Only $1 \%$ of workers hired between 2000 and 2004, after the program began, became sensitized. Air levels of beryllium were similar for the two 
time periods. Since these prevention results are from a single plant and cover a relatively short period of time, the results should be considered encouraging but preliminary. Additional follow-up over longer periods and at other beryllium workplaces remains to be performed.

\section{CASE STUDIES}

\section{Case 1}

Two years after starting work at a berylliumusing facility, a secretary was moved to an area in which beryllium laboratory testing had been done years earlier. The following year, her work area was renovated, including opening the ventilation duct work. She developed skin problems, including itching and raised lesions, which she believed were due to the dust from renovation. Five months after renovation, she had her first abnormal BeLPT blood test which was confirmed the following month. She was then evaluated for chronic beryllium disease: no granulomas or other abnormalities were found in lung biopsy samples; her lung lymphocytes (obtained through lavage) were elevated (22\%); and testing of her lung lavage cells did not indicate lung sensitization. She left work the following year. A second medical evaluation, 16 months after the first, then found granulomas in the biopsy samples and further elevation of lung lavage lymphocytes (36\%). At that time she was diagnosed with chronic beryllium disease.

\section{Case 2}

A beryllium worker took part in medical surveillance after spending more than 20 years in different production jobs and as a foreman. He did not wear a respirator. He reported no cough, wheeze, or shortness of breath. His first blood samples were sent to two laboratories, and one BeLPT was abnormal. The following month, a second set of samples was sent to two laboratories, and both were abnormal, confirming that he was sensitized. His medical evaluation showed granulomas in his lung biopsy samples, elevated lung lavage lymphocytes (27\%), and an abnormal lung lavage BeLPT, all of which supported the diagnosis of chronic beryllium disease. His participation in medical surveillance, along with other workers', contributed to the development of a more comprehensive preventive program at his facility.

What do these cases illustrate? Case 1 shows us that sometimes those who don't work directly with beryllium, but who are exposed to beryllium-containing dust, can develop chronic beryllium disease. It also shows that continued monitoring of the health of sensitized workers is important; this person's chronic beryllium disease was not diagnosed until her second medical evaluation and after she left employment. Case 2 shows us the value of participating in workplace medical surveillance. This person had no symptoms and would not have known he had chronic beryllium disease if he had not participated in the medical surveillance that was offered to him. His participation helped to guide efforts to protect his fellow workers, as well as future workers.

\section{CURRENT EXPOSURE LIMITS}

Current beryllium exposure limits and action levels from various agencies and groups are provided below.

\section{$\mathrm{NIOSH}$}

In 1977, NIOSH suggested a REL of $0.5 \mu \mathrm{g} / \mathrm{m}^{3}$ to reduce the risk of beryllium-related lung 
cancer [25]. This REL does not prevent beryllium sensitization or chronic beryllium disease. Since a safe exposure limit for beryllium has not been determined, NIOSH recommends that employers keep airborne concentrations of beryllium as low as possible.

\section{OSHA}

The current OSHA PEL for beryllium is 2.0 $\mathrm{\mu g} / \mathrm{m}^{3}$ as an 8-hour time-weighted average (TWA) [26]. OSHA has stated that the current PEL may not adequately protect berylliumexposed workers from developing chronic beryllium disease [27, 28]. Other OSHA exposure limits for beryllium are a ceiling concentration of $5.0 \mathrm{\mu g} / \mathrm{m}^{3}$, and a maximum peak concentration of $25.0 \mathrm{\mu g} / \mathrm{m}^{3}$ for a maximum duration of 30 minutes [26].

\section{DOE}

The U.S. Department of Energy (DOE) requires various actions to limit exposures to beryllium (including engineering and administrative controls and the use of respiratory protection). The DOE also requires medical surveillance using the BeLPT to be offered when airborne concentrations of beryllium exceed an action level. In 1999, the DOE set a beryllium exposure action level (8-hour TWA) of $0.2 \mu \mathrm{g} / \mathrm{m}^{3}$ [26]. In addition, the DOE building-surface contamination level for beryllium in work areas during nonoperational periods is $3.0 \mu \mathrm{g} / 100 \mathrm{~cm}^{2}$ of surface area. The concentration of beryllium on items released to the public must not exceed 0.2 $\mu \mathrm{g} / 100 \mathrm{~cm}^{2}$ [26]. These surface contamination levels are based on technical feasibility rather than on documented risk for sensitization and disease.

\section{Other Limits}

In 2009, the American Conference of Governmental Industrial Hygienists (ACGIH) adopted a new Threshold Limit Value $\left(\operatorname{TLV}^{\circledR}\right)$ for beryllium of $0.05 \mu \mathrm{g} / \mathrm{m}^{3}$ as an 8-hour TWA for inhalable particulate matter, and added notations for "sensitizer" and "skin"; no ShortTerm Exposure Limit (STEL) was included [29]. In 2007, the State of California adopted a new PEL of $0.2 \mu \mathrm{g} / \mathrm{m}^{3}$ 8-hour TWA [30]. The Canadian province of Quebec has adopted a limit of $0.15 \mu \mathrm{g} / \mathrm{m}^{3}$ 8-hour TWA [31]. In Europe, 8-hour TWA exposure limits range from $0.2 \mu \mathrm{g} / \mathrm{m}^{3}$ inhalable aerosol (Spain) to $2.0 \mu \mathrm{g} / \mathrm{m}^{3}$ (e.g., United Kingdom) [32]. The Japanese occupational exposure limit is 2.0 $\mathrm{\mu g} / \mathrm{m}^{3}$ 8-hour TWA [32]. China's permissible concentration (8-hour TWA) is $0.5 \mathrm{\mu g} / \mathrm{m}^{3}$ [33].

\section{OTHER RESOURCES}

More information about beryllium is available through the following resources:

\section{NIOSH}

Respirators:

www.cdc.gov/niosh/topics/respirators/

Searchable database:

www2a.cdc.gov/nioshtic-2/default.asp

Pocket guide to chemical hazards:

www.cdc.gov/niosh/npg/pgintrod.html

International chemical safety cards:

www.cdc.gov/niosh/ipcs/icstart.html

Sampling/analytical methods:

www.cdc.gov/niosh/docs/2003-154/

\section{OSHA}

Hazard Information Bulletin: Preventing Adverse Health Effects from Exposure to Beryllium on the Job [28], www.osha.gov/dts/hib/ hib_data/hib19990902.html 
Hazard Information Bulletin: Preventing $A d-$ verse Health Effects from Exposure to Beryllium in Dental Laboratories [34], www.osha. gov/dts/hib/hib_data/hib020419.html

Safety and Health Topics: Beryllium, www. osha.gov/SLTC/beryllium/index.html

\section{Other}

Brush Wellman Inc. Interactive Guide to Working Safely with Beryllium and Beryllium-Containing Materials, www.berylliumsafety.com ${ }^{\dagger}$

Committee on Beryllium Alloy Exposures, Committee on Toxicology, National Research Council. Health Effects of Beryllium Exposure: A Literature Review, www.nap.edu/catalog/12007.html ${ }^{\dagger}$

Committee on Beryllium Alloy Exposures, Committee on Toxicology, National Research Council. Managing Health Effects of Beryllium Exposure [20], www.nap.edu/catalog/12464.html ${ }^{\dagger}$

Department of Energy: Title 10 CFR Part 850 Chronic Beryllium Disease Prevention Program, www.hss.energy.gov/HealthSafety/ wshp/be/index.html ${ }^{\dagger}$

Department of Labor: Energy Employees Occupational IIIness Compensation Program, www.dol.gov/owcp/energy/ ${ }^{\dagger}$

National Jewish Health. Chronic Beryllium Disease: Overview, www.nationaljewish.org/ healthinfo/conditions/beryllium-disease/ index.aspx ${ }^{\dagger}$

\footnotetext{
${ }^{\dagger}$ By accessing this information, you will be directed to an external website that is not controlled by NIOSH or the U.S. Department of Health and Human Services. Links to websites outside of NIOSH are offered for your convenience in accessing related information, but do not constitute an endorsement of the website or its contents by NIOSH. NIOSH takes no responsibility for the accuracy, relevance, timeliness, or completeness of the information contained on non-NIOSH websites.
}

\section{CONCLUSIONS}

Workers in various sectors of the beryllium industry are at risk of developing serious respiratory disease following exposure to beryllium. More action is needed to (1) identify workers exposed to beryllium who may not know that they are exposed, (2) improve protective measures for exposed workers, (3) reduce/minimize both overall exposures and, when possible, the number of exposed workers, (4) educate workers about the hazards of working with beryllium, (5) determine the characteristics of exposures (e.g., particle size, shape, surface area, and chemical form) that are associated with increased risk, and (6) identify industrial and occupational sectors that use beryllium and target them for prevention efforts.

\section{RECOMMENDATIONS}

NIOSH recommends that workers exposed to particles, fumes, mists, or solutions from beryllium-containing materials take the following steps to protect themselves:

Understand the risks and follow all proper procedures for working with berylliumincluding participation in safety training.

Keep beryllium out of the lungs:

- Make sure that beryllium dusts, fumes, mists, and beryllium-containing solutions and suspensions are controlled at their sources.

- Participate in respiratory protection programs when advised to do so.

Keep beryllium-containing dusts and solutions off the skin: 
- Keep work surfaces and work areas clean.

- Participate in skin protection programs. These programs may include wearing gloves and company-issued clothing (with long sleeves and long pants) and showering at the end of the workday.

- Do not store or consume food, drinks, tobacco products, or cosmetics in beryllium work areas.

- Do not use cleaning methods that may cause dust to become resuspended in air (dry sweeping, compressed air, and other dust-generating methods, for example). Better methods include HEPA-filtered vacuums or wet cleaning methods that do not produce splash or spray.

- Prevent beryllium dusts and other contaminants from leaving beryllium work areas on your skin, clothing, shoes, and tools.

- Participate in workplace medical surveillance so that risks related to job tasks can be identified and prevented.

Seek medical attention for any chronic cough or shortness of breath, which may indicate chronic beryllium disease.

Seek medical attention for any rash or non-healing cut or wound.

NIOSH recommends that employers of workers exposed to particles, fumes, mists, or solutions from beryllium-containing materials take the following steps to protect workers, contractors, and visitors:

Know the beryllium content of all materials in the workplace. The manufacturers or suppliers of materials containing greater than $0.1 \%$ beryllium are required to provide this information on Material Safety Data Sheets.
Substitute less hazardous materials for those containing beryllium whenever feasible.

Minimize the number of workers exposed to beryllium dusts, fumes, mists, and beryllium-containing solutions and suspensions.

Install, use, and maintain effective engineering controls for processes that create beryllium dusts, fumes, mists, and beryllium-containing solutions and suspensions.

Keep airborne concentrations of beryllium as low as possible, since a safe exposure limit for beryllium has not been determined.

Monitor airborne beryllium concentrations to document the effectiveness of efforts to reduce airborne exposures.

Inform workers about the risks of beryllium sensitization, chronic beryllium disease, and lung cancer, and the proper procedures for working with berylliumcontaining materials.

Keep beryllium dusts, fumes, mists, and beryllium-containing solutions and suspensions confined to the immediate work area.

Do not use cleaning methods that may cause dust to become resuspended in air (dry sweeping, compressed air, and other dust-generating methods, for example). Better methods include HEPA-filtered vacuums or wet cleaning methods that do not produce splash or spray.

Prevent beryllium dusts and other contaminants from leaving beryllium work areas on workers' skin, clothing, shoes, and tools. 
- Identify and clean areas outside the beryllium work zone that may have become contaminated before these recommendations were implemented.

- Establish and maintain an appropriate respiratory protection program as needed.

- Establish and maintain a skin protection program to protect workers' skin from contamination with beryllium dusts and solutions:

- Keep work surfaces and work areas clean.

- Provide work gloves, long-sleeved shirts, long pants, and shoes that remain at the workplace.

- Provide showering and changing facilities.

Conduct medical surveillance for sensitization using the beryllium lymphocyte proliferation test for workers who come in contact with beryllium dusts, fumes, mists, and beryllium-containing solutions and suspensions:

- Identify higher-risk jobs and processes to prioritize prevention efforts and evaluate their effectiveness in decreasing the risk of sensitization.

- Ensure that sensitized workers identified through surveillance are referred for medical testing (1) to determine whether they have chronic beryllium disease, (2) to establish radiographic and lung function baselines for followup testing, and (3) receive counseling.

\section{ACKNOWLEDGMENTS}

Principal contributors to this Alert were Christine R. Schuler, Ph.D.; Gregory A. Day, Ph.D.;
Paul K. Henneberger, Sc.D., M.P.H.; Ainsley Weston, Ph.D.; Mark D. Hoover, Ph.D.; and Kathleen Kreiss, M.D. John D. Piacentino, M.D., provided significant guidance and review.

Marcia Stanton served as program coordinator. Susan Afanuh, Jane Weber, and Anne Hamilton provided editorial and production services. Vanessa B. Williams and Gino Fazio provided graphic design and production services.

Please direct comments, questions, or requests for additional information to the following:

\section{Director}

Division of Respiratory Disease Studies

National Institute for Occupational Safety and Health

1095 Willowdale Road

Morgantown, WV 26505-2888

We greatly appreciate your assistance in protecting the health of U.S. workers.

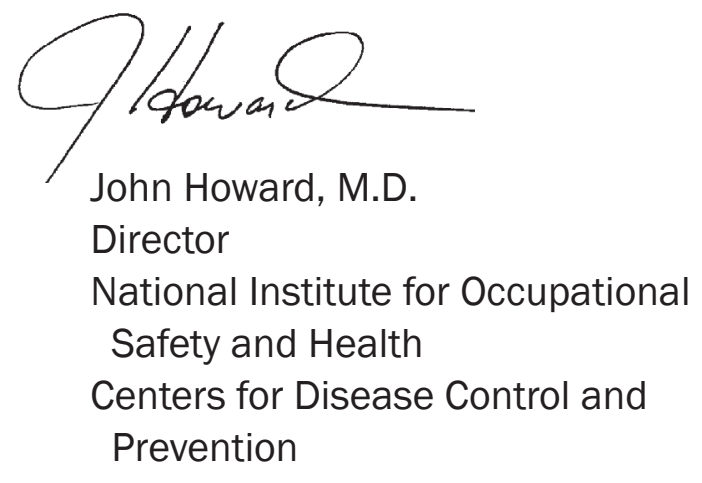

\section{REFERENCES}

1) Kreiss K, Mroz MM, Zhen B, Martyny JW, Newman LS [1993]. Epidemiology of beryllium sensitization and disease in nuclear workers. Am Rev Respir Dis 148(4 Part 1):985-991. 
2) Kreiss K, Day GA, Schuler CR [2007]. Beryllium: a modern industrial hazard. Annu Rev Public Health 28:259-277.

3) Newman LS, Mroz MM, Balkissoon R, Maier LA [2005]. Beryllium sensitization progresses to chronic beryllium disease: a longitudinal study of disease risk. Am J Respir Crit Care Med 171(1):54-60.

4) NTP [2002]. Beryllium (CAS No. 744041-7) and beryllium compounds. Report on carcinogens. $11^{\text {th }}$ ed. Washington, DC: U.S. Department of Health and Human Services, Public Health Service, National Toxicology Program [http://ntp.niehs.nih.gov/ntp/roc/ eleventh/profiles/s022bery.pdf].

5) IARC Monograph Working Group [2009]. Special report: policy: a review of human carcinogens-part C: metals, arsenic, dusts, and fibres. Lancet 10:453-454.

6) Deubner D, Kelsh M, Shum M, Maier L, Kent M, Lau E [2001]. Beryllium sensitization, chronic beryllium disease, and exposures at a beryllium mining and extraction facility. Appl Occup Environ Hyg 16(5):579-592.

7) Henneberger PK, Cumro D, Deubner D, Kent MS, McCawley M, Kreiss K [2001]. Beryllium sensitization and disease among long-term and short-term workers in a beryllium ceramics plant. Int Arch Occup Environ Health 74(3):167-176.

8) Kreiss K, Mroz MM, Newman LS, Martyny J, Zhen B [1996]. Machining risk of beryllium disease and sensitization with median exposures below $2 \mathrm{\mu g} / \mathrm{m}^{3}$. Am J Ind Med 30(1):16-25.

9) Kreiss K, Mroz MM, Zhen B, Wiedemann H, Barna B [1997]. Risk of beryllium disease related to work processes at a metal, alloy, and oxide production plant. Occup Environ Med 54(8):605-612.
10) Kreiss $K$, Wasserman $S$, Mroz MM, Newman LS [1993]. Beryllium disease screening in the ceramics industry. Blood lymphocyte test performance and exposure-disease relations. J Occup Med 35(3):267-274.

11) Newman LS, Mroz MM, Maier LA, Daniloff EM, Balkissoon R [2001]. Efficacy of serial medical surveillance for chronic beryllium disease in a beryllium machining plant. J Occup Environ Med 43(3):231-237.

12) Rosenman K, Hertzberg $V$, Rice $C$, Reilly MJ, Aronchick J, Parker JE, Regovich J, Rossman M [2005]. Chronic beryllium disease and sensitization at a beryllium processing facility. Environ Health Perspect 113:1366-1372.

13) Sackett HM, Maier LA, Silveira $\sqcup$, Mroz MM, Ogden LG, Murphy JR, Newman LS [2004]. Beryllium medical surveillance at a former nuclear weapons facility during cleanup operations. J Occup Environ Med 46(9):953-961.

14) Schuler CR, Kent MS, Deubner DC, Berakis MT, McCawley M, Henneberger PK, Rossman MD, Kreiss K [2005]. Process-related risk of beryllium sensitization and disease in a copper-beryllium alloy facility. Am J Ind Med 47:195-205.

15) Schuler CR, Kitt MM, Henneberger PK, Deubner DC, Kreiss K [2008]. Cumulative sensitization and disease in a beryllium oxide ceramics worker cohort. J Occup Environ Med 50:1343-1350.

16) Stange AW, Furman FJ, Hilmas DE [2004]. The beryllium lymphocyte proliferation test: relevant issues in beryllium health surveillance. Am J Ind Med 46(5):453-462.

17) Stange AW, Hilmas DE, Furman FJ, Gatliffe TR [2001]. Beryllium sensitization and chronic beryllium disease at a former nuclear weapons facility. Appl Occup Environ Hyg 16(3):405-417. 
18) Taiwo OA, Slade MD, Cantley LF, Fiellin MG, Wesdock JC, Bayer FJ, Cullen MR [2008]. Beryllium sensitization in aluminum smelter workers. J Occup Environ Med 50(2):157-162.

19) Welch L, Ringen K, Bingham E, Dement J, Takaro T, McGowan W, Chen A, Quinn P [2004]. Screening for beryllium disease among construction trade workers at Department of Energy nuclear sites. Am J Ind Med 46(3):207-218.

20) Committee on Beryllium Alloy Exposures, Committee on Toxicology, National Research Council [2008]. Managing health effects of beryllium exposure. Washington, DC: The National Academies Press. [www. nap.edu/catalog/12464.html].

21) Curtis GH [1951]. Cutaneous hypersensitivity due to beryllium: a study of thirteen cases. AMA Arch Dermatol Syph 64(4):470-482.

22) Tinkle SS, Antonini JM, Rich BA, Roberts JR, Salmen R, DePree K, Adkins EJ [2003]. Skin as a route of exposure and sensitization in chronic beryllium disease. Environ Health Perspect 111(9):1202-1208.

23) Cummings KJ, Deubner DC, Day GA, Henneberger PK, Kitt MM, Kent M, Kreiss K, Schuler CR [2007]. Enhanced preventive programme at a beryllium oxide ceramics facility reduces beryllium sensitisation among new workers. Occup Environ Med 64(2):134-140.

24) Deubner D, Kent M [2007]. Keeping beryllium workers safe: an enhanced preventive model (commentary). J Occup Environ Hyg 4:D23-D30.

25) NIOSH [1977]. Public hearing on the occupational standard for beryllium: statement of Edward J. Baier, NIOSH deputy director. U.S. Department of Labor, Occupational Safety and Health Administration, August 19.

26) CFR. Code of Federal regulations. Washington, DC: U.S. Government Printing Office, Office of the Federal Register.

27) OSHA [1998]. Letter from Assistant Secretary Charles N. Jeffress to Peter Brush, Acting Assistant Secretary for Environment, Safety and Health, U.S. Department of Energy, August 27.

28) OSHA [1999]. Preventing adverse health effects from exposure to beryllium on the job. Washington, DC: U.S. Department of Labor, Occupational Safety and Health Administration, OSHA Hazard Information Bulletin 99-09-02 [www.osha.gov/dts/hib/hib_data/ hib19990902.html].

29) ACGIH [2009]. TLVs $^{\circledR}$ and BEls ${ }^{\circledR}$ : based on the documentation of the threshold limit values for chemical substances and physical agents and biological exposure indices. Cincinnati, OH: American Conference of Governmental Industrial Hygienists.

30) California Code of Regulations, Title 8, Section 5155, Table AC-1 [2007]. [http:// www.dir.ca.gov/title8/5155ac1Frame.html].

31) Gazette Officielle du Québec [2005]. Béryllium [7440-41-7]. Métal et composés (exprimée en $\mathrm{Be})=0,00015 \mathrm{mg} / \mathrm{m}^{3}$. Gazette Officielle du Québec 137(31):4.

32) Institut für Arbeitsschutz der Deutschen Gesetzlichen Unfallversicherung [2010]. GESTIS International Limit Values for Chemical Agents: Occupational Exposure Limits (OELs) [http:// bgia-online.hvbg.de/LIMITVALUE/WebForm_ gw.aspx]. Date accessed: May 28, 2010. 
33) Ministry of Health, People's Republic of China [2007]. Occupational exposure limits for hazardous agents in the workplace, part 1: chemical hazardous agents, GBZ 2.1-2007 [http://www.moh.gov.cn/publicfiles/business/ cmsresources/zwgkzt/cmsrsdocument/doc 3277.pdf]. Date accessed: June 2, 2010.
34) OSHA [2002]. Preventing adverse health effects from exposure to beryllium in dental laboratories. Washington, DC: U.S. Department of Labor, Occupational Safety and Health Administration, OSHA Hazard Information Bulletin 02-04-19 [www.osha.gov/dts/ hib/hib_data/hib020419.html]. 



\section{Appendix}

\section{Examples of Beryllium Industries and Products}

Note: Health risks exist if beryllium-containing materials are dispersed as a dust, fume, mist, or beryllium-containing solution or suspension that can be inhaled or come into contact with unprotected skin.

Aerospace: Altimeters, braking systems, bushings and bearings for landing gear, electronic and electrical connectors, engines, gyroscopes, mirrors (e.g., space telescopes), precision tools, rockets, satellites, structural components, and missile guidance systems.

Automotive: Air-bag triggers, antilock brake system terminals, electronic and electrical connectors, steering wheel connecting springs, and valve seats for drag racer engines.

Biomedical: Dental bridges, partials, and other prostheses, medical laser and scanning electron microscope components, and X-ray windows.

Decommissioning and decontamination of worksites: Various beryllium-containing materials.

Defense: Heat shields, mast-mounted sights, missile guidance systems, nuclear weapon components, submarine hatch springs, and tank mirrors.

Energy and electrical: Heat exchanger tubes, microelectronics, microwave devices, nuclear reactor components, oil field drilling and exploring devices, and relays and switches.

Fire prevention: Nonsparking tools and sprinkler system springs.

Instruments, equipment, and objects: Bellows, camera shutters, clock and watch gears and springs, commercial speaker domes, computer disk drives, musical instrument valve springs, pen clips, and commercial phonograph styluses.

Manufacturing: Injection molds for plastics, and bearings.

Other metals: Aluminum smelting and nonferrous metal foundries.

Sporting goods and jewelry items: Golf clubs, beryl and chrysoberyl gemstones (including aquamarine, emerald, and alexandrite), and manmade emerald and other gemstones with distinctive colors.

Scrap recovery and recycling: Various beryllium-containing products.

Telecommunications: Cellular telephone components, electromagnetic shields, electronic and electrical connectors, personal computer components, rotary telephone springs and connectors, undersea repeater housings, and transistor mountings (integrated circuit substrates). 
NOTES 
NOTES 


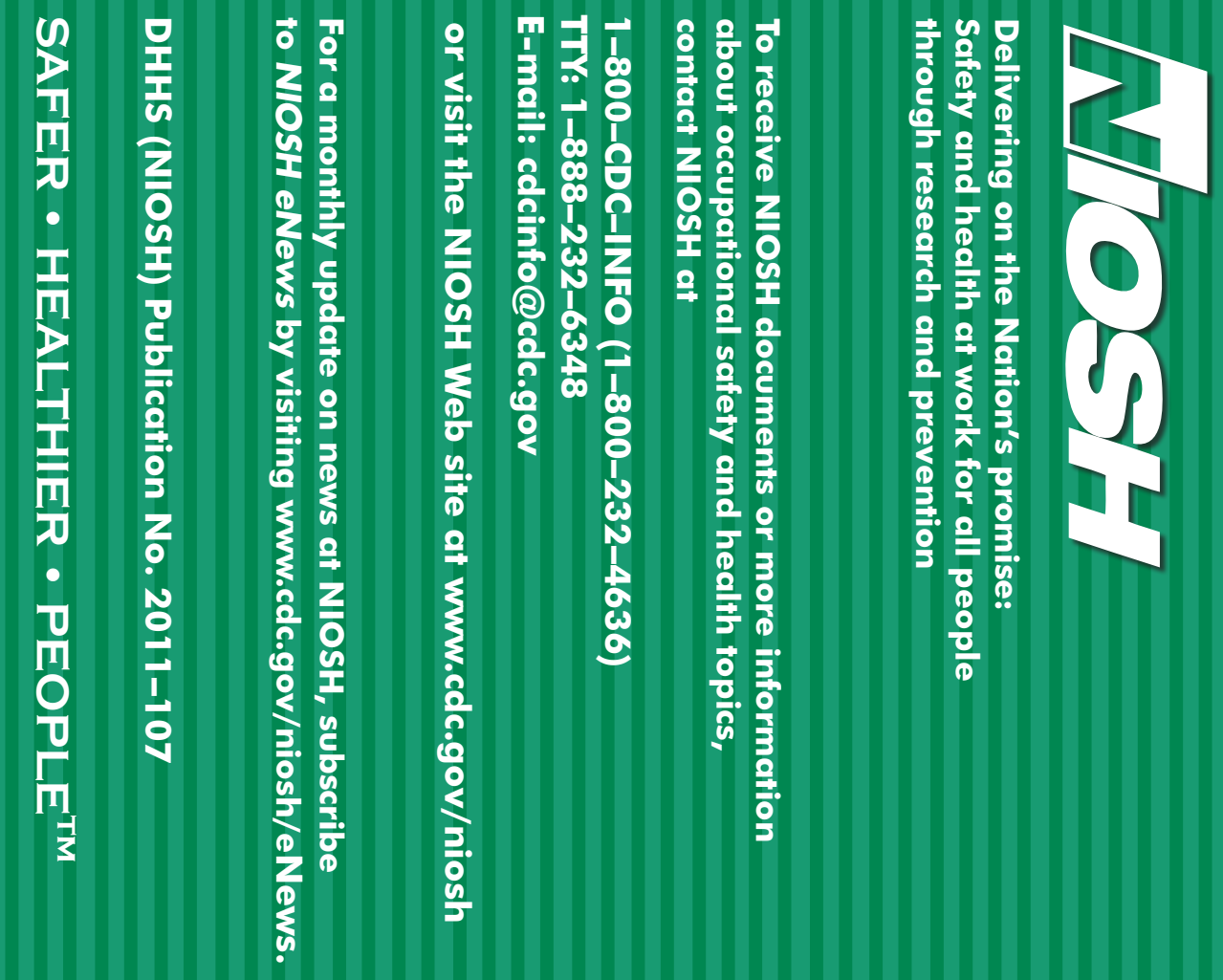

DEPARTMENT OF HEALTH AND HUMAN SERVICES

Centers for Disease Control and Prevention

National Institute for Occupational Safety and Health

4676 Columbia Parkway

Cincinnati, Ohio 45226-1998

Official Business

Penalty for Private Use $\mathbf{\$ 3 0 0}$ 